\title{
Antitumoral effect of arsenic compound, sodium metaarsenite (KML001), on multiple myeloma cells
}

\author{
SEO JU KIM ${ }^{1}$, EUN SHIL KIM ${ }^{1}$, SUJONG KIM ${ }^{2}$, JIEUN UHM ${ }^{1}$, YOUNG WOONG WON ${ }^{1}$, \\ BYEONG BAE PARK ${ }^{1}$, JUNG HYE CHOI ${ }^{1}$ and YOUNG YIUL LEE ${ }^{1}$ \\ ${ }^{1}$ Department of Internal Medicine, Hanyang University College of Medicine, Seoul; \\ ${ }^{2}$ Pharmaceutical Division, Komipharm International Co., Ltd., Gyeonggi-do, Republic of Korea
}

Received June 2, 2017; Accepted September 21, 2017

DOI: 10.3892/ijo.2017.4161

\begin{abstract}
KML001 (sodium metaarsenite; $\mathrm{NaAs}_{2} \mathrm{O}_{3}$ ) is known to have antitumor activity against a variety of cancers. In this study, we examined its effect on multiple myeloma (MM). KML001 reduced the growth of all MM cell lines examined with an $\mathrm{IC}_{50}$ of $5 \times 10^{-8} \mathrm{M}$. Exposure to KML001 $\left(5 \times 10^{-8} \mathrm{M}\right)$ decreased levels of cyclins A/B1/D1/E1, CDK2/4/6 in U266 cells and increased the p21 and p27 levels. Furthermore, p21 became bound to CDK2/4/6, resulting in a reduction of CDK2/4/6 kinase activity. The cleaved forms of Bcl-2, and caspases-3, -8 and -9 were detected, and the anti-apoptotic molecule, Bax, also increased. Activation of STAT1/3, NF- $\kappa$ B (p65 and p50 subunits), pAKT and pERK decreased, and p-PTEN increased. There was also a significant reduction of hTERT at $12 \mathrm{~h}$ and upregulation of $\gamma-\mathrm{H}_{2} \mathrm{~A}_{\mathrm{X}}$ and CHK1/2 molecules at $24 \mathrm{~h}$. Thus, KML001 appears to have antitumor activity against MM by inhibiting various oncogenic signaling pathways. It may be useful for treating MM.
\end{abstract}

\section{Introduction}

Multiple myeloma (MM) is a plasma cell neoplasm, characterized by an enlarged population of clonal B-cells in the bone marrow (1), overproduction of a monoclonal immunoglobulin (Ig) in the blood and/or urine, and damage to end organs, including osteolytic bone lesions, renal impairment, hypercalcemia and anemia $(2,3)$.

In spite of advances in many therapeutic strategies, MM remains an incurable hematologic neoplasm. Moreover, MM patients are susceptible to relapse and drug resistance (2,4-6). Therefore, a new treatment is needed for treating MM patients.

Correspondence to: Professor Young Yiul Lee, Division of Hematology/Oncology, Department of Internal Medicine, Hanyang University Hospital, 222-1 Wangsimni-ro, Seongdong-gu, Seoul 04763, Republic of Korea

E-mail: leeyy@hanyang.ac.kr

Key words: multiple myeloma, KML001, cell cycle, cell signaling, telomere
Arsenic trioxide (ATO; $\mathrm{As}_{2} \mathrm{O}_{3}$ ), an FDA-approved drug for acute promyelocytic leukemia (APL), is a well-known anticancer drug. It has been shown to be effective against various solid cancer cell lines (7-9). However, it has to be administered intravenously, and it is questionable whether it can be the cornerstone of treatment for solid tumors and other hematologic neoplasms (10).

KML001 (sodium metaarsenite; $\mathrm{NaAsO}_{2}$ ) is a water-soluble, therefore, orally bioavailable, arsenical compound (11-13). It has been suggested that one of its mechanisms of action is to target the telomeres of malignant cells (11).

In this study, using human MM cells and analyzing the cell cycle, apoptosis, signaling pathways for cell growth, telomere lengths, and DNA damage, we present the first evidence for an antitumor action of MM.

\section{Materials and methods}

Cell lines and cell culture. The MM cell lines RPMI8226, U266, IM-9, MC/CAR, KMS.11, and MM1.S were obtained from the ATCC (Rockville, MD, USA) and maintained following a protocol provided by the ATCC. RPMI-1640 medium (Gibco-BRL, Gaithersburg, MD, USA) supplemented with $10 \%$ (vol/vol) fetal bovine serum (FBS; Hyclone Labs, Inc., Logan, UT, USA), $100 \mathrm{U} / \mathrm{ml}$ penicillin and $100 \mu \mathrm{g} / \mathrm{ml}$ streptomycin (Sigma Chemical Co., St. Louis, MO, USA) was used to culture the cells in tissue flasks. The cultures were maintained in a humidified atmosphere with $5 \% \mathrm{CO}_{2}$ at $37^{\circ} \mathrm{C}$. The culture medium was changed every 3-4 days.

Reagents. KML001 was acquired from Komipharm International (Gyeonggi-Do, Korea). It was dissolved at $10^{-3} \mathrm{M}$ in distilled water and aliquots were stored at $4^{\circ} \mathrm{C}$. The stock solution was stable for more than a year, and was diluted with RPMI-1640 medium daily to obtain working concentrations. $\mathrm{As}_{2} \mathrm{O}_{3}$ was purchased from Sigma-Aldrich Corp. (St. Louis, MO, USA). A $5 \times 10^{-2} \mathrm{M}$ stock solution was prepared in $5 \mathrm{M}$ $\mathrm{NaOH}$ and aliquots were stored at $4^{\circ} \mathrm{C}$.

In vitro cytotoxicity assays using MTT. The in vitro cytotoxicity of KML001 for myeloma cells was assessed with MTT (3-[4,5-dimethylthiazol-2yl]-2,5-diphenyltetrazolium bromide) by measuring dye absorption by living cells. In brief, cells 

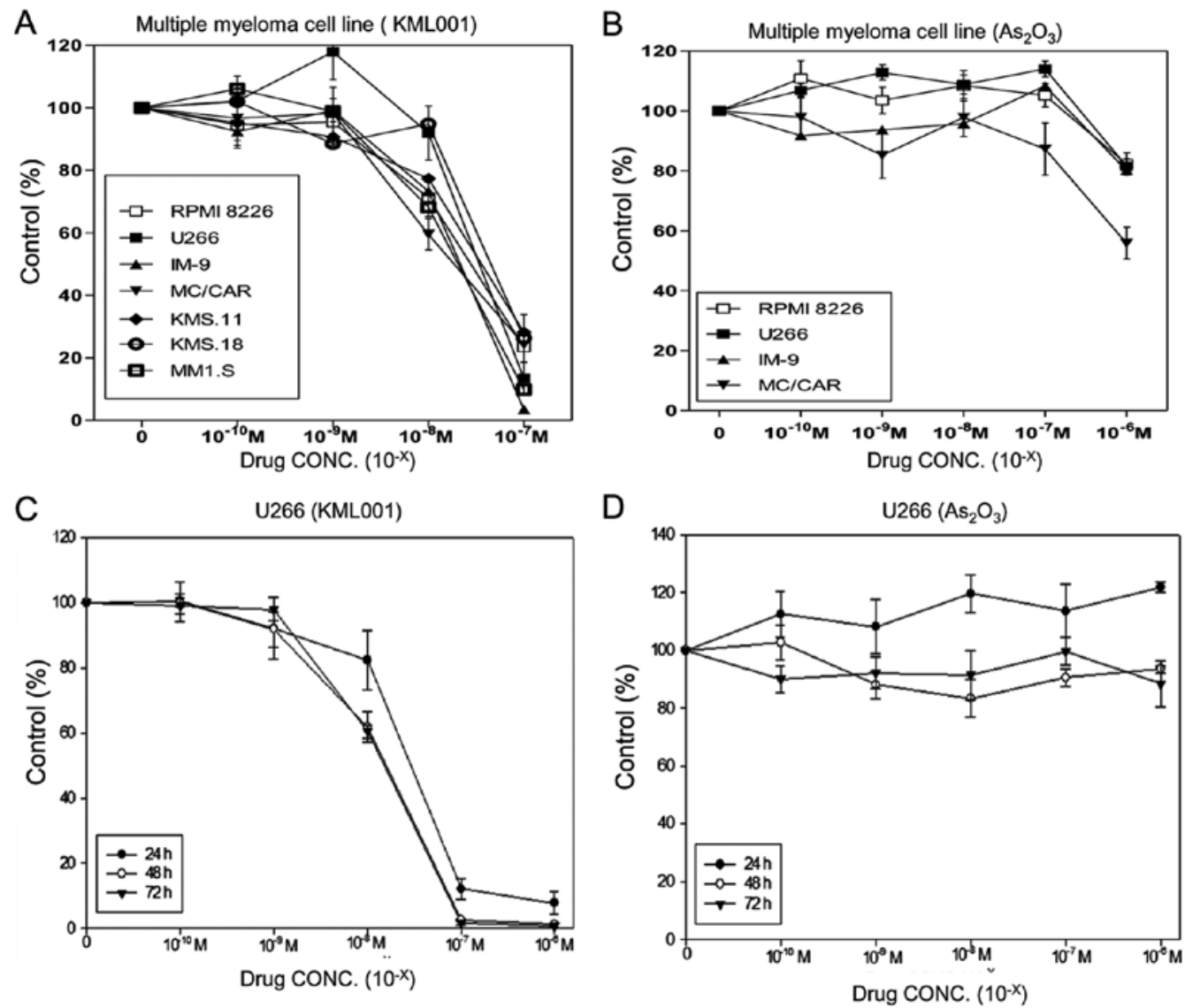

Figure 1. Effect of KML001 and $\mathrm{As}_{2} \mathrm{O}_{3}$ on growth of human multiple myeloma cells. (A) Logarithmically growing human MM cell lines were incubated with various doses of KML001 for $72 \mathrm{~h}$. (B) The MM cell lines were incubated with various doses of $\mathrm{As}_{2} \mathrm{O}_{3}$ for $72 \mathrm{~h}$. (C) U266 cells were incubated with various doses of KML001 for 24, 48 and 72 h. (D) U266 cells were incubated with various doses of $\mathrm{As}_{2} \mathrm{O}_{3}$ for 24, 48 and 72 h. Cell cytotoxicity was assessed with the MTT assay. Results are expressed as percentage of control plates containing no KML001 or $\mathrm{As}_{2} \mathrm{O}_{3}$. Each point represents the mean ( \pm SD) of at least three independent experiments with triplicate dishes.

(1x10 4 cells/well) were seeded in 96-well plates and incubated for 3 days at $37^{\circ} \mathrm{C}$ with $5 \% \mathrm{CO}_{2}$. Then, $50 \mu \mathrm{l}$ of MTT (Sigma) solution $(2 \mathrm{mg} / \mathrm{ml}$ in PBS) was added to each well and incubation continued for $4 \mathrm{~h}$ at $37^{\circ} \mathrm{C}$. DMSO $(200 \mu \mathrm{l} /$ well $)$ was added and the absorbance at $540 \mathrm{~nm}$ was recorded using an iMark microplate absorbance reader (Bio-Rad, Hercules, CA, USA).

In vitro apoptosis assay. Apoptosis was observed by staining cells with Annexin V-FITC and PI labeling. Quantification of apoptosis of cells was achieved by washing prepared cells twice with cold PBS and re-suspending them in binding buffer (10 mM HEPES/NaOH, pH 7.4, $140 \mathrm{mM} \mathrm{NaCl}, 2.5 \mathrm{mM} \mathrm{CaCl}_{2}$ ) at $1 \times 10^{6}$ cells $/ \mathrm{ml}$. One hundred microliters of the resulting suspension $\left(1 \times 10^{5}\right.$ cells) was transferred to a $5-\mathrm{ml}$ culture tube containing $5 \mu \mathrm{l}$ of Annexin V-FITC (Pharmingen, San Diego, CA, USA) and $10 \mu \mathrm{l}$ of $20 \mu \mathrm{g} / \mathrm{ml}$ PI (Sigma). The cells were vortexed and allowed to incubate for $15 \mathrm{~min}$ at room temperature in the dark. Following the addition of $400 \mu \mathrm{l}$ of binding buffer, the cells were analyzed by FACStar flow cytometry (Becton-Dickinson, CA, USA).

Western blot analysis. Whole lysates $(20 \mu \mathrm{g})$ were resolved on the $10 \%$ SDS-PAGE gels, and transferred to a nitrocellulose membranes (Bio-Rad) by electro-blotting. Antibodies to CDK2, CDK4, CDK6, cyclin A, cyclin B1, cyclin D1, cyclin E, p21, p27, Bcl-2, Bax, caspase-3, -8 and -9, pChk1,
pChk2, p65, p50 (Santa Cruz Biotechnology, Santa Cruz, CA, USA), pSTAT1, STAT, pSTAT3, STAT3, pSTAT5, pAKT, AKT, pmTOR, mTOR, pPTEN, PTEN, pP38, p38, pERK, ERK, pJNK, JNK (Cell Signaling, MA, USA), and $\mathrm{p}-\boldsymbol{\gamma}-\mathrm{H}_{2} \mathrm{~A}_{\mathrm{X}}$ (Ser139) (Upstate Biotechnology, NY, USA) were used for western blotting.

Immunoprecipitation (IP) and kinase assays. Samples of $250 \mu \mathrm{g}$ total protein were incubated with anti-CDK2, anti-CDK4, and anti-CDK6 polyclonal antibodies for $16 \mathrm{~h}$ at $4^{\circ} \mathrm{C}$ with continuous agitation. Protein A/G-agarose $(25 \mu \mathrm{l})$ was added to the mixtures and, centrifuged at 1,200 rpm for $2 \mathrm{~min}$, and the resulting pellets were washed 3 times with extraction buffer to collect immune complexes. SDS-polyacrylamide denaturing gels were used to resolve the immune complexes; the resolved proteins, were then transferred to nitrocellulose membranes, and probed with the anti-p27 antibody. An ECL kit (Intron, Korea) was used to develop the blots.

For the kinase assay, immune complexes were washed twice with kinase reaction buffer [50 mM Tris- $\mathrm{Cl}$ (pH 7.5), $10 \mathrm{mM}$ $\mathrm{MgCl}_{2}$ and $1 \mathrm{mM}$ DTT]. CDK2, CDK4 and CDK6 kinase assays with histone $\mathrm{H} 1$ as substrate were performed by mixing the respective immune complexes with $5 \mu \mathrm{g}$ of histone $\mathrm{H} 1$ and $1 \mu \mathrm{Ci}\left[\gamma^{-}{ }^{32} \mathrm{P}\right] \mathrm{ATP}$ in $30 \mu \mathrm{l}$ of kinase reaction buffer. Kinase reactions were performed at $37^{\circ} \mathrm{C}$ for $30 \mathrm{~min}$ and terminated with $2 X$ SDS-PAGE loading buffer. After boiling for $5 \mathrm{~min}$, 
the reaction products were separated electrophoretically on $12 \%$ SDS-PAGE gels, and analyzed by autoradiography to detect phosphorylated proteins.

Quantitative hTERT real-time PCR. Total RNA was isolated using TRI reagent (Molecular Research Center, Inc., Cincinnati, $\mathrm{OH}$, USA), and cDNAs were synthesized from $1 \mu \mathrm{g}$ of total RNA using SuperScript-II Reverse Transcriptase (Invitrogen, Carlsbad, CA, USA) with random hexamers. Quantitative PCR was performed with a Lightcycler 480 II (Roche Diagnostics Corp.) using SYBR Green I as a double-strand DNA-specific binding dye. Quantitative hTERT real-time PCR was performed as described previously (14).

TRF length analysis. A TeloTAGG telomere restriction fragment (TRF) length kit was used, according to the instructions provided by the manufacturer (Roche Diagnostics GmbH, Mannhein, Germany). In brief, $10 \mu \mathrm{g}$ of genomic DNA was digested with a 6-fold excess of restriction enzymes $H i n f I$ and $R s a \mathrm{I}$ at $37^{\circ} \mathrm{C}$ for $2 \mathrm{~h}$. The resulting DNA digest was fractionated by electrophoresis on a $0.8 \%$ agarose gel and transferred to a nylon membrane by southern blotting. The DNA was fixed to the membrane by UV-crosslinking $(120 \mathrm{~mJ})$, and the immobilized DNA fragments were hybridized with digoxigenin-labelled telomere-specific probes (3'-TTAGGG-5'). The resulting hybrids were detected with anti-digoxigenin coupled to alkaline phosphatase, which metabolizes the chemiluminescent substrate, CDP-Star. The membrane was then exposed to X-ray film.

Statistical analysis. Data are presented as means \pm SDs, and were analyzed with Student's t-test. Probability values of $<0.05$ were considered to be statistically significant.

\section{Results}

Cytotoxic effect of KML001 on multiple myeloma cell lines. Significant dose-dependent inhibition of cell growth was observed in all of seven cell lines after treatment of KML001 for $72 \mathrm{~h}$ (Fig. 1A). KML001 at $5 \times 10^{-8} \mathrm{M}$ exhibited $>50 \%$ inhibition of growth in all cell lines. $\mathrm{As}_{2} \mathrm{O}_{3}$ was less effective than KML001 in four MM cell lines: RPMI-1640, U266, IM-9 and MC/CAR (Fig. 1B). KML001 inhibited the proliferation of $\mathrm{U} 266$ cells in a time-dependent manner, while $\mathrm{As}_{2} \mathrm{O}_{3} \mathrm{did}$ not (Fig. 1C and D).

Levels of cell cycle-regulatory molecules in KML001-treated U266 cells. Levels of CDK2, CDK4, CDK6, cyclin A, cyclin B1, cyclin D1 and cyclin E were reduced in KML001-treated U266 cells, but unaltered in $\mathrm{As}_{2} \mathrm{O}_{3}$-treated cells (data not shown). Levels of p21 and p27, which negatively regulate various cyclin/CDK complexes, increased in a time-dependent manner (Fig. 2), suggesting that KML001 inhibited cell cycle arrest in U266 cells.

Association of $p 21$ and p27 with CDK2, CDK4, and CDK6 in KML001-treated U266 cells. Since western blot analysis showed that KML001 induced marked accumulation of CDK inhibitors (p21 and p27), we determined whether the p21 and p27 proteins induced by KML001 $\left(5 \times 10^{-8} \mathrm{M}\right.$ for $\left.72 \mathrm{~h}\right)$ could be detected as complexes with CDKs. As shown in Fig. 3A,

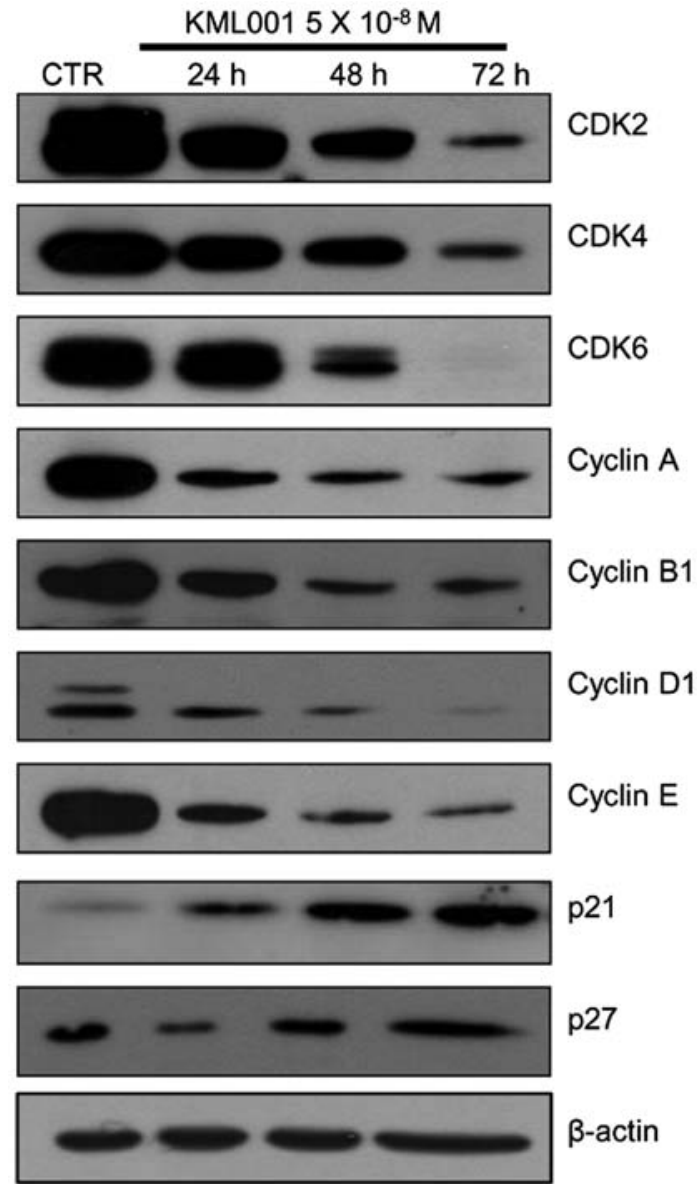

Figure 2. Effect of KML001 on cell cycle-related proteins in U266 cells Cells were harvested after incubation with $5 \times 10^{-8}$ M KML001 for 24, 48 and $72 \mathrm{~h}$. Samples of $20 \mu \mathrm{g}$ of total protein were analyzed by $12 \%$ SDS-PAGE, transferred to a nitrocellulose membrane and immunoblotted with the indicated antibodies. $\beta$-actin was used as a loading control.

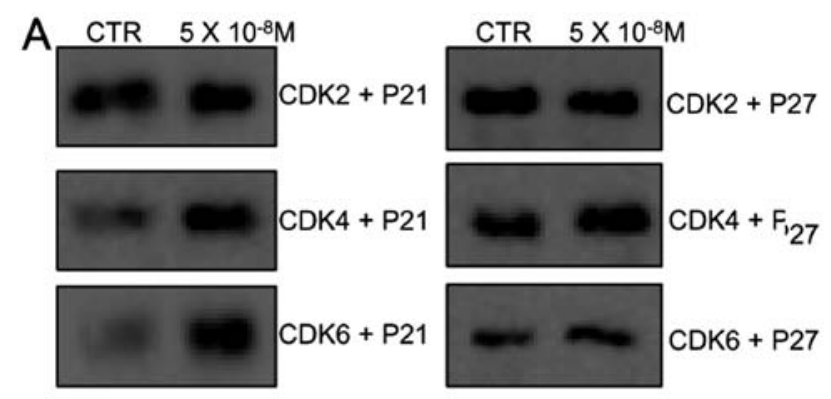

B

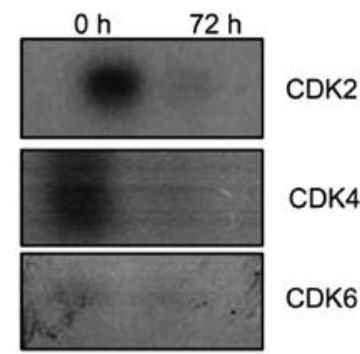

Figure 3. Effect of KML001 on binding of CDKI to CDKs, and CDK-associated histone $\mathrm{H} 1$ kinase activities. (A) U266 cells were incubated with $5 \times 10^{-8} \mathrm{M}$ KML001 for $72 \mathrm{~h}$, and immunoprecipitated with CDK2, CDK4 and CDK6 antibodies. The reaction mixtures were separated by $12 \%$ SDS-PAGE and subjected to western blot analysis with anti-p21 and anti-p27 antibodies. (B) Lysates were prepared, and CDK2, CDK4, and CDK6 kinase activities were determined in histone H1 kinase assays. 

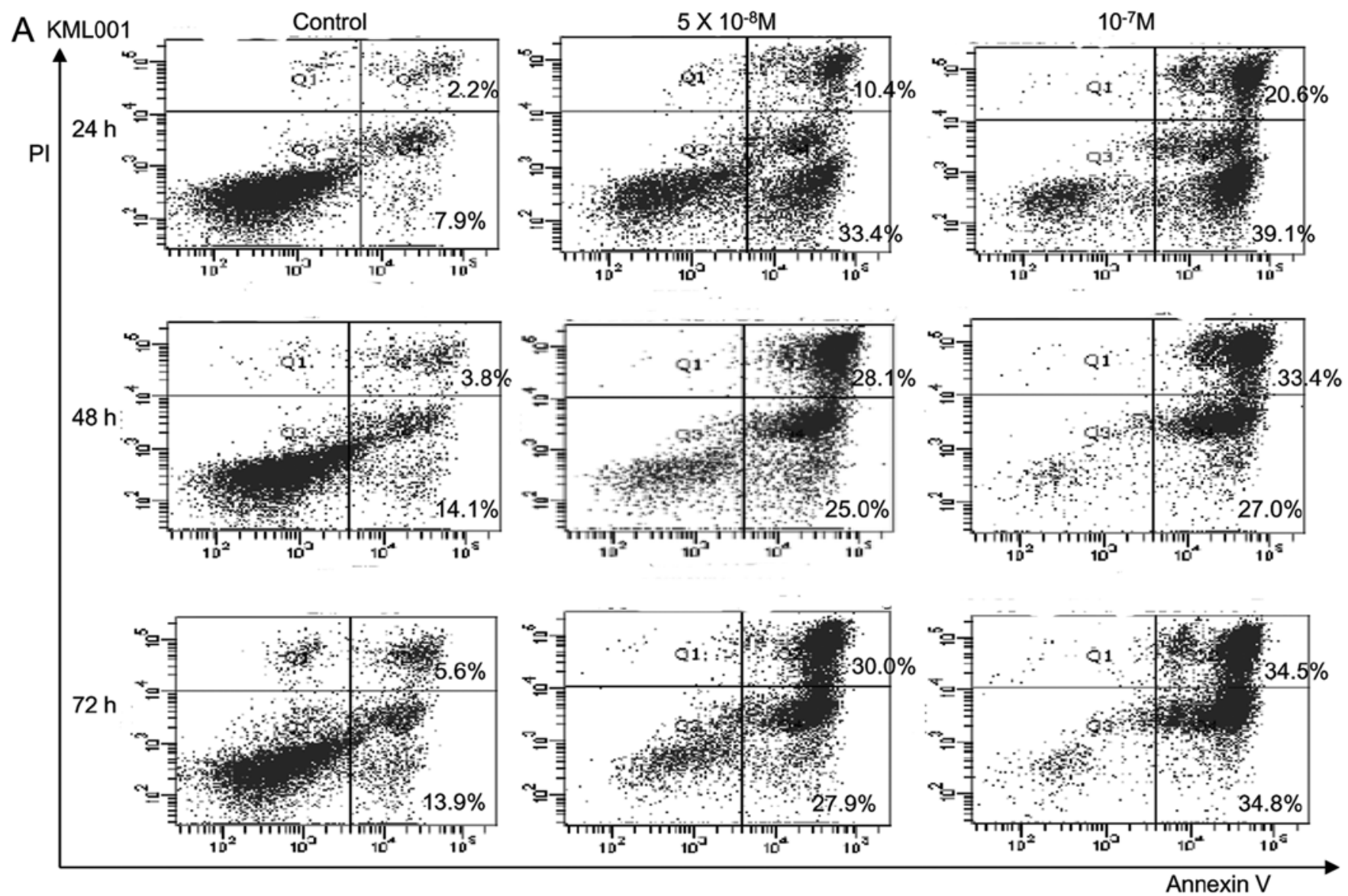

B
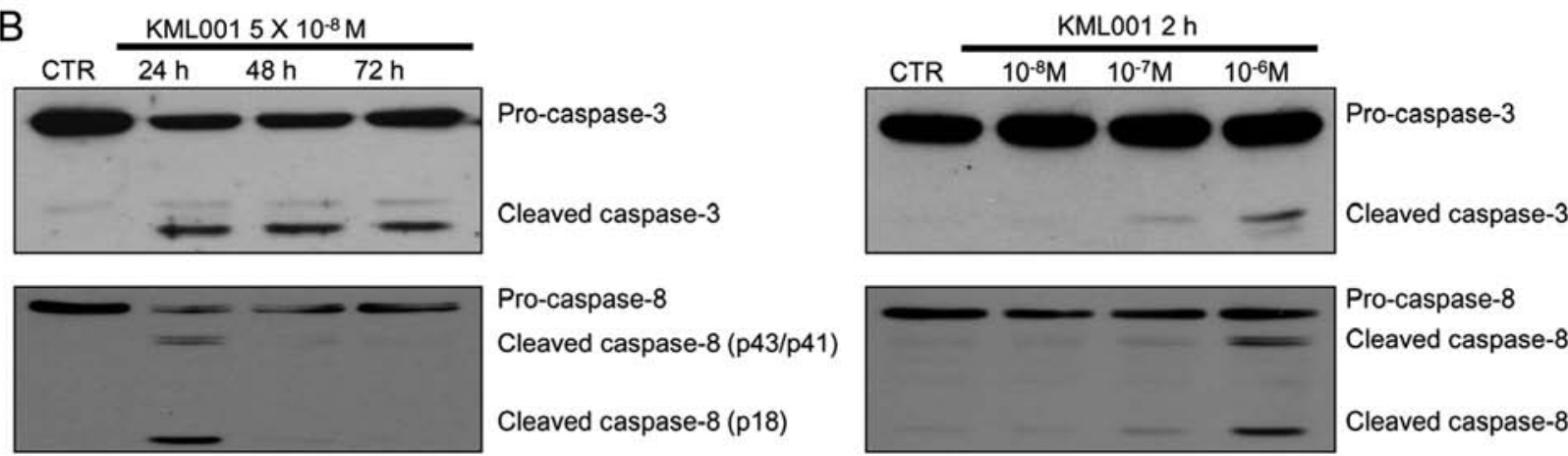

Pro-caspase-8

Cleaved caspase-8 (p43/p41)

Cleaved caspase-8 ( $p 18)$

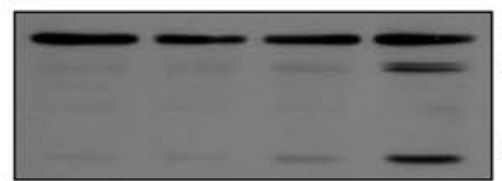

Pro-caspase-8

Cleaved caspase-8 (p43/p41)

Cleaved caspase-8 ( $p 18)$

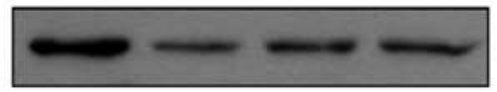

Pro-caspase-9
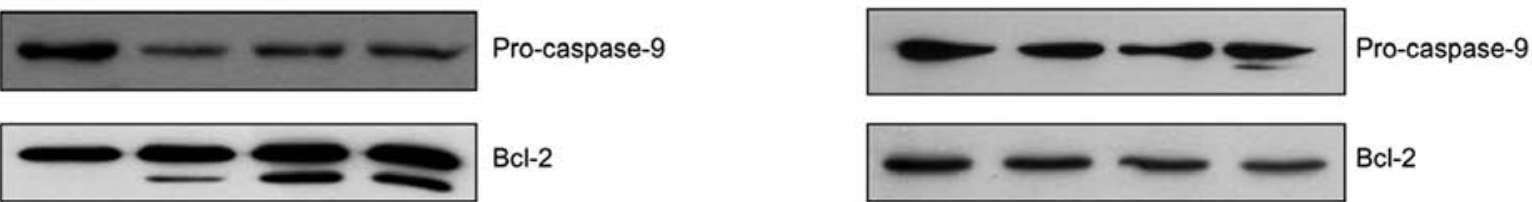

$\mathrm{Bcl}-2$
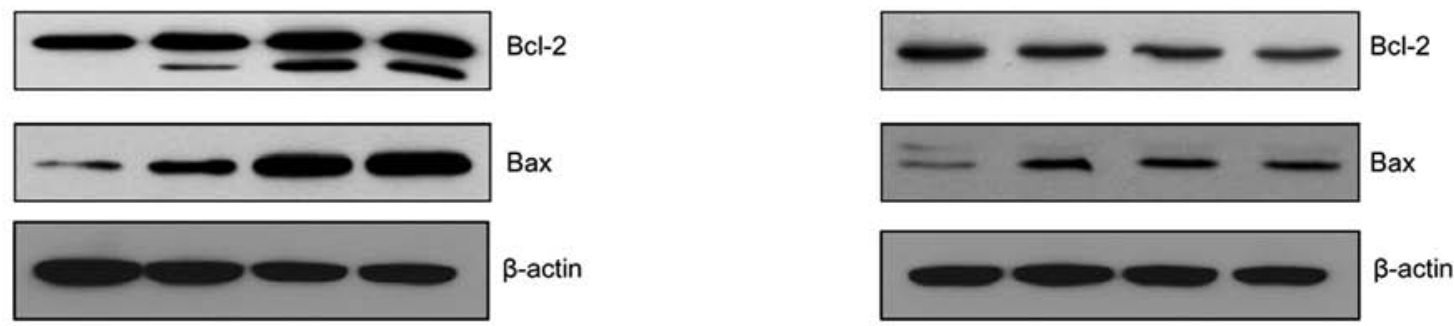

Figure 4. Effect of KML001 on apoptosis in U266 cells. (A) To detect apoptosis by FACS analysis, KML001-exposed U266 cells were stained with Annexin V-FITC and PI. (B) Cells were incubated with the indicated concentrations of KML001 for the indicated times. Whole cell lysates were analyzed by western blotting for caspase- $3,-8$ and $-9, \mathrm{Bcl}-2$ and Bax.

CDK complexes immunoprecipitated from KML001-treated U266 cells with anti-CDK2,-CDK4 and -CDK6 antibodies contained larger amounts of p21 and p27 proteins than those immunoprecipitated from untreated cells. This suggest that the p21 and p27 proteins inhibit CDK2, CDK4 and CDK6 activities by direct binding to these CDKs. 


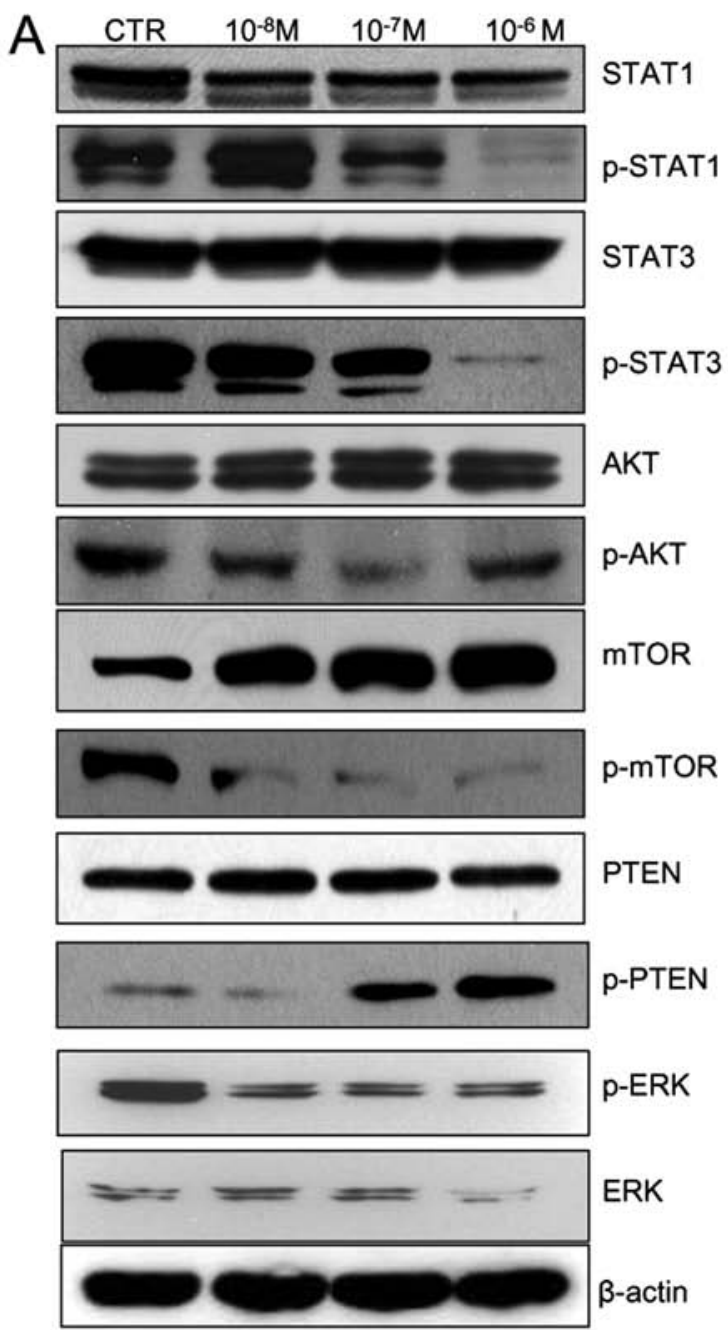

B
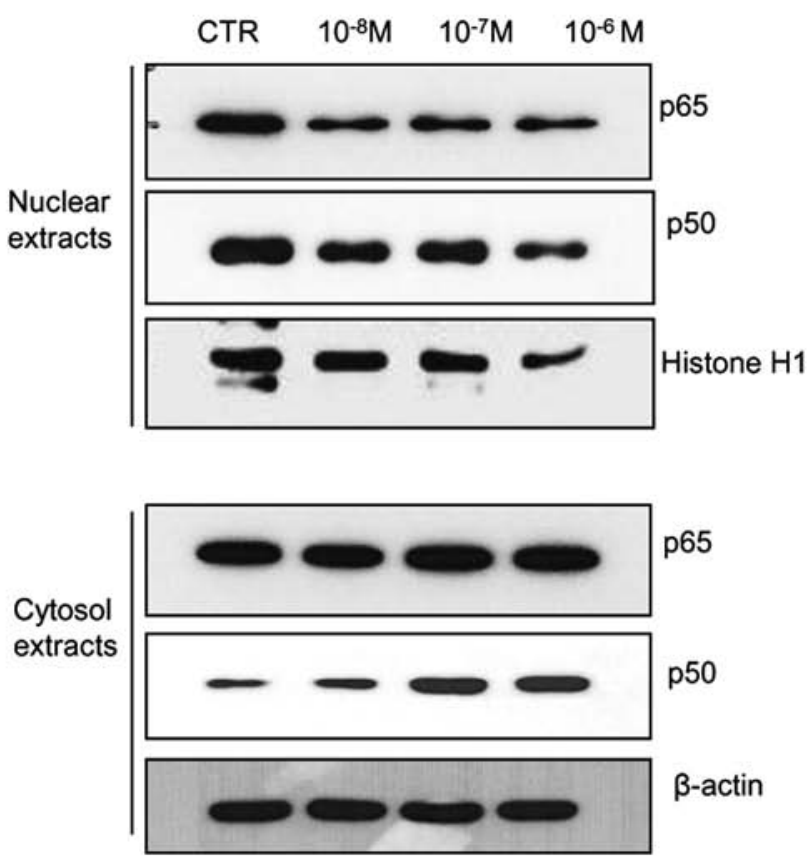

Figure 5. The effect of KML001 on cell signaling pathways. (A) Regulation of the STAT, PI3K/Akt and MAPK signaling pathways in U266 cells. (B) Regulation of the NF- $\mathrm{KB}$ signaling pathway in U266 cells. Cells were harvested at $2 \mathrm{~h}$ and western blots were performed with the indicated antibodies.

CDK-associated kinase activity in KML001-treated U266 cells. In order to determine whether binding of the CDK inhibitors (p21 and p27) resulted in the inhibition of CDK activity, in vitro CDK activity assays were performed. A dramatic decrease in CDK2-, CDK4- and CDK6-associated kinase activities was observed in KML001-treated U266 cells (Fig. 3B). These results suggest that KML001 inhibits the G1 phase cell cycle arrest via reducing CDK2-, CDK4-, and CDK6 kinase activities through the binding of p21 and p27 proteins.

Induction of apoptosis by KML001 in U266 cells. In order to determine whether KML001 treatment induced apoptosis in U266 cells, apoptosis was detected by FACS analysis. As shown in Fig. 4A, treatment of U266 cells with KML001 led to an increase in the proportion of Annexin V-FITC-stained cells. With $10^{-7}$ M KML001, 59.7\% of the cells were either apoptotic or dead.

With regard to changes in Bcl-2 family members, Bax was increased by treatment with KML001, and Bcl-2 decreased (Fig. 4B). These observations suggested that apoptosis might be mediated by activation of the pro-apoptotic protein Bax and downregulation of the anti-apoptotic protein
$\mathrm{Bcl}-2$. We therefore measured the activation of caspases by KML001. As shown in Fig. 4B, the cleaved forms of initiator caspase- 3 and -8 increased while procaspase- 9 declined. Thus KML001-induced apoptosis was accompanied by a reduction of Bcl-2 level and increased caspase activities.

Effect of KMLO01 on cell signaling. One of the most important oncogenic signaling pathways involves STAT proteins. To investigate the role of STAT molecules in KML001-treated U266 cells, STAT proteins were determined by immunoblotting. STAT proteins levels were not changed by KML001 treatment, but the phosphorylated forms of STAT1 and 3 declined in a dose-dependent manner. Regarding the Akt signaling pathway, KML001 decreased p-Akt and p-mTOR levels. In addition, p-PTEN increased in a dose-dependent manner, and pERK (p44/42) (Fig. 5A) and the p65 and p50 subunits of NF- $\mathrm{KB}$ (Fig. 5B) decreased. These results suggested that the cytotoxic effect of KML001 is mediated through a number of oncogenic signaling pathways.

Effect of KMLO01 on telomere-related DNA damage signals. Uncapped telomeres are recognized as DNA damage. Formation of the phosphorylated form of $\gamma-\mathrm{H}_{2} \mathrm{~A}_{\mathrm{X}}$ represents 


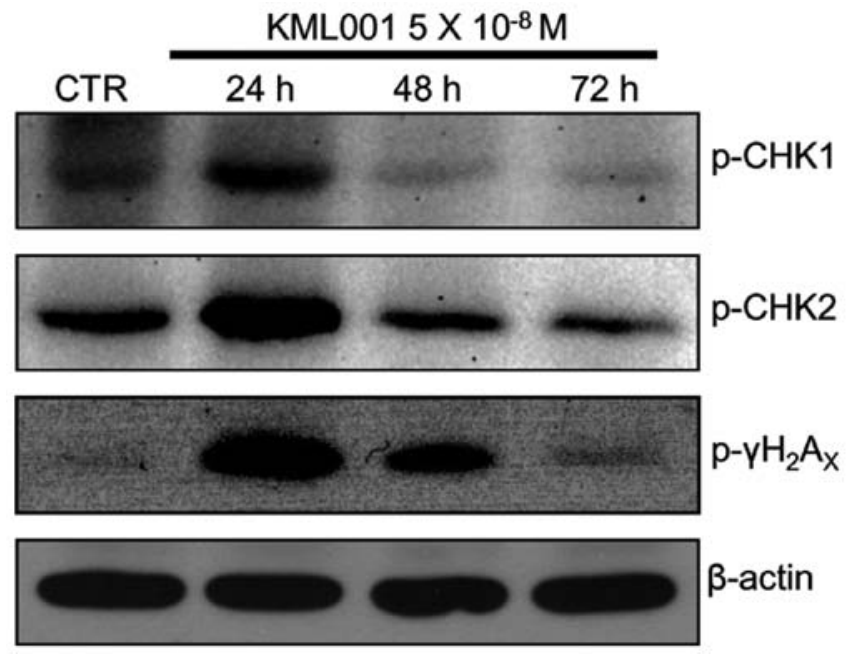

Figure 6. Effect on DNA damage signals in KML001-exposed U266 cells Western blotting of p-CHK1, p-CHK2, and p- $\gamma-\mathrm{H}_{2} \mathrm{Ax}$ was performed on lysates of KML001-treated U266 cells. $\beta$-actin were used as the loading control.

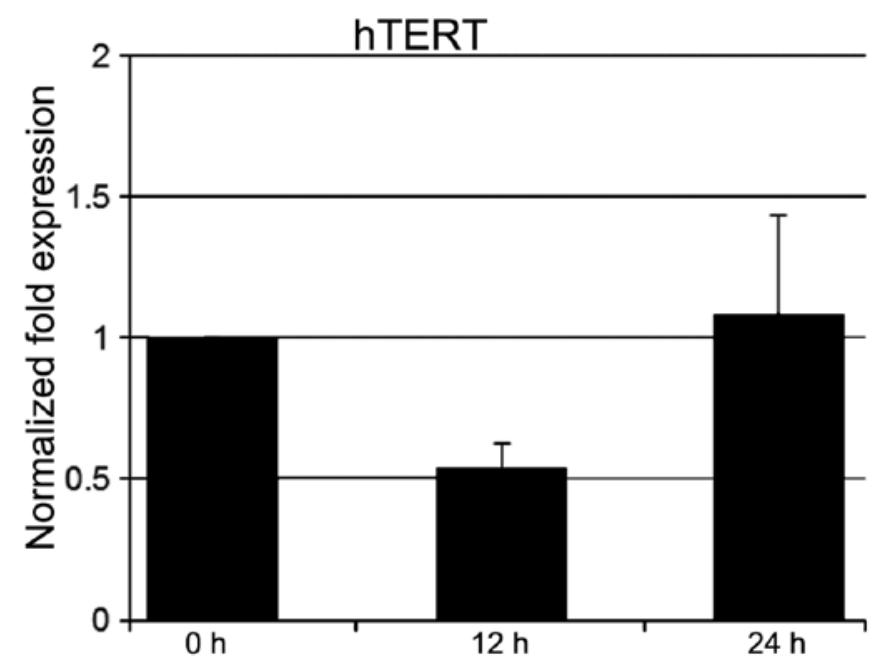

Figure 7. Effect of KML001 on hTERT mRNA in U266 cells. hTERT mRNA expression was measured by qRT-PCR after treatment with KML001. The experiments were performed in triplicates.

a very early event in DNA damage signaling of double-strand breaks $(15,16)$. Therefore, $\mathrm{p}-\gamma-\mathrm{H}_{2} \mathrm{~A}_{\mathrm{X}}$ is a hallmark of the cellular response to DNA double strand breaks (DSB). We found that $\mathrm{p}-\gamma-\mathrm{H}_{2} \mathrm{~A}_{\mathrm{X}}$ increased significantly at $24 \mathrm{~h}$ KML001 treatment (Fig. 6). DNA damaging agents cause single strand DNA (ssDNA) and double-strand break (DSB) lesions, which initiate activation of ATR-Chk1 and ATM-Chk2, respectively $(17,18)$. Phosphorylated Chk1 and Chk2 increased significantly in 24 h-treated U266 cells (Fig. 6).

Effect of KMLO01 on hTERT expression and telomere length. Telomerase activity has been found in $>85 \%$ of human tumors. We asked whether KML001 altered the level of the mRNA or the catalytic subunit of telomerase, human telomere reverse transcriptase (hTERT). Real-time PCR analysis, showed that hTERT mRNA expression decreased in $12 \mathrm{~h}$-treated U266 cells (Fig. 7).

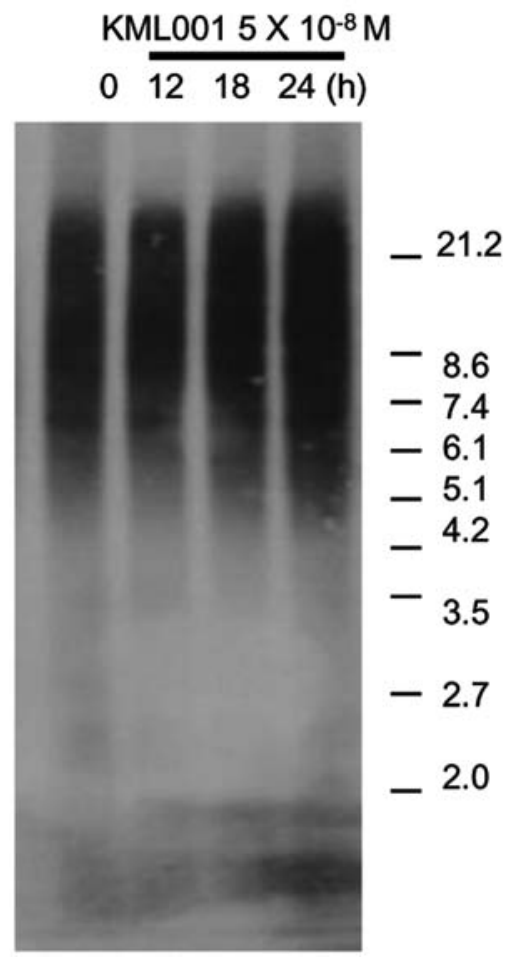

Figure 8. Telomere lengths in KML001-treated U266 cells. Cells were incubated with KML001 $\left(5 \times 10^{-8} \mathrm{M}\right)$ for 12,18 and $24 \mathrm{~h}$. Telomere length was analyzed using a Roche Diagnostics TRF assay kit. The experiments were performed in triplicate.

It has been shown that KML001 binds to human telomeric sequences and causes rapid erosion of the telomeres of cancer cells (19). Using southern blots of terminal restriction fragements (TRFs) we investigated the effect of KML001 on U266 telomeres. We observed no reduction of TRF length by, KML001 treatment for up to $24 \mathrm{~h}$ (Fig. 8).

\section{Discussion}

We showed above that KML001 inhibited the growth all $7 \mathrm{MM}$ cell lines in a dose-dependent manner and $\mathrm{As}_{2} \mathrm{O}_{3}$ was less effective. We also observed that KML001 inhibited the growth of U266 cells by inducing G1 arrest and apoptosis, and reduced levels of cyclin D1, cyclin E, CDK2, CDK4, and CDK6.

KML001 treatment increased levels of the CDK inhibitors p21 and p27, which bound to CDK2,CDK4, and CDK6 proteins and lowered CDK2, CDK4, and CDK6 kinase activities.

Taken together, our results suggest that KML001 causes G1 cell cycle arrest via inhibition of CDK2, CDK4, and CDK6 kinase activities by $\mathrm{p} 21$ and p27.

We observed apoptosis using Annexin V/PI double staining in KML001-treated U266 cells. Apoptotic cells increased in a time-dependent manner and KML001 induced downregulation of anti-apoptotic Bcl-2 and upregulation of pro-apoptotic Bax in a time- and dose-dependent manner.

Apoptosis is initiated by caspases, a large family of cysteine protease enzymes (20). It requires the activation of initiator caspases (caspase-8 and -9) and executioner caspases (caspases-3 and -7). Cleaved-caspase-8, -9 and -3 were detected in KML001-treated U266 cells. Taken together, these 
observations provide strong KML001 induces apoptosis of U266 cells.

Key signaling pathways in cancer include the STAT, the MAPK and PI3K/Akt pathway. In this study, the phosphorylated forms of STAT1 and 3 were decreased in $2 \mathrm{~h}$ KML001-treated cells, the phosphorylated forms of ERK decreased, phosphorylated PTEN increased and phosphorylated Akt/mTOR decreased.

$\mathrm{NF}-\kappa \mathrm{B} / \mathrm{Rel}$ proteins are dimers composed of p65 and p50 subunits involved in various cell signaling pathways including survival, proliferation and inflammation. We showed previously that the expression of p65 and p50 was reduced in hematologic cancer cells after exposure to $\operatorname{KML001}(14,21)$. In this study, we demonstrated that p65 and p50 levels were reduced by exposure to KML001.

Telomeres, the nucleoprotein caps, are composed of the telomeric repeat sequences $(\mathrm{TTAGGG})_{\mathrm{n}}$ at the ends of eukaryotic chromosomes that protect chromosomes from degradation, end-to-end fusion, and recombination $(22,23)$. As a result, telomere uncapping can cause a cellular response to DNA double strand breaks (DSB). Phosphorylation of $\gamma-\mathrm{H}_{2} \mathrm{~A}_{\mathrm{X}}$ at Ser139 is an early event in DSB-DDR (DNA damage response) $(15,16)$. In the present study, phosphorylated $\gamma-\mathrm{H}_{2} \mathrm{~A}_{\mathrm{X}}$ increased significantly in U266 cells following KML001 treatment.

DNA damaging agents generate SSB and/or DSB lesions. Typically, ssDNA initiates ATR-Chk1 activation, and DSB lesion are initiated by ATM-Chk2 activation $(17,18)$. In this study, KML001 significantly increased the levels of phosphorylated Chk1 and Chk2 in U266 cells, suggesting that it might impair the telomeres.

Telomerase activity has been found in $85-90 \%$ of human tumors. However, it is not found in most normal human somatic cells, which lack hTERT $(24,25)$. Previous studies showed that arsenic inhibits the transcription of hTERT (26). We also confirmed that the mRNA level of hTERT decreased as early as $12 \mathrm{~h}$ after treatment of KML001 in U266 cells, and we showed previously that KML001 induced telomere restriction fragment (TRF) length shortening in non-Hodgkin's lymphoma cells (14). However, we detected no restriction fragment (TRF) length shortening in U266 cells after exposure to KML001 for $72 \mathrm{~h}$. Wang et al reported that an oligonucleotide telomerase template antagonist induced telomeric shortening following 14-day treatment of multiple myeloma (27). Therefore, the absence of telomeric shortening in our results might be due to the shorter treatment ( $24 \mathrm{~h})$ with KML001.

We showed previously that KML001 had no severe side effects in nude mice. In addition, non-Hodgkin's lymphoma patients treated with KML001 showed no severe side effects except for grade I/II anorexia and nausea (14). In unpublished clinical study we treated $3 \mathrm{MM}$ patients who had relapsed and were refractory to conventional and high-dose chemotherapies with KML001, and obtained partial responses (data not shown).

In conclusion, we have demonstrated that KML001 inhibits the proliferation of human multiple myeloma cell lines and that it acts by inducing cell cycle arrest, triggering apoptosis and inhibiting various cell signaling pathways. Consequently, KML001 could be an effective agent for treating $\mathrm{MM}$ patients.

\section{Acknowledgements}

This study was conducted in the Hanyang University Hospital Clinical Laboratory, and this study was supported by Komipharm International Co., Ltd., Gyeonggi-do, Korea.

\section{References}

1. Hallek M, Bergsagel PL and Anderson KC: Multiple myeloma: Increasing evidence for a multistep transformation process. Blood 91: 3-21, 1998.

2. Palumbo A and Anderson K: Multiple myeloma. N Engl J Med 364: 1046-1060, 2011.

3. Raab MS, Podar K, Breitkreutz I, Richardson PG and Anderson KC: Multiple myeloma. Lancet 374: 324-339, 2009.

4. Kumar SK, Rajkumar SV, Dispenzieri A, Lacy MQ, Hayman SR, Buadi FK, Zeldenrust SR, Dingli D, Russell SJ, Lust JA, et al: Improved survival in multiple myeloma and the impact of novel therapies. Blood 111: 2516-2520, 2008.

5. Laubach J, Richardson P and Anderson K: Multiple myeloma. Annu Rev Med 62: 249-264, 2011.

6. Mahindra A, Laubach J, Raje N, Munshi N, Richardson PG and Anderson K: Latest advances and current challenges in the treatment of multiple myeloma. Nat Rev Clin Oncol 9: 135-143, 2012.

7. Ling YH, Jiang JD, Holland JF and Perez-Soler R: Arsenic trioxide produces polymerization of microtubules and mitotic arrest before apoptosis in human tumor cell lines. Mol Pharmacol 62: 529-538, 2002.

8. Uslu R, Sanli UA, Sezgin C, Karabulut B, Terzioglu E, Omay SB and Goker E: Arsenic trioxide-mediated cytotoxicity and apoptosis in prostate and ovarian carcinoma cell lines. Clin Cancer Res 6: 4957-4964, 2000.

9. Zhang TC, Cao EH, Li JF, Ma W and Qin JF: Induction of apoptosis and inhibition of human gastric cancer MGC-803 cell growth by arsenic trioxide. Eur J Cancer 35: 1258-1263, 1999.

10. Litzow MR: Arsenic trioxide. Expert Opin Pharmacother 9: 1773-1785, 2008.

11. Phatak P, Dai F, Butler M, Nandakumar MP, Gutierrez PL, Edelman MJ, Hendriks H and Burger AM: KML001 cytotoxic activity is associated with its binding to telomeric sequences and telomere erosion in prostate cancer cells. Clin Cancer Res 14: 4593-4602, 2008.

12. Woo SR, Ham Y, Kang W, Yang H, Kim S, Jin J, Joo KM and Nam DH: KML001, a telomere-targeting drug, sensitizes glioblastoma cells to temozolomide chemotherapy and radiotherapy through DNA damage and apoptosis. BioMed Res Int 2014: $747415,2014$.

13. Yang MH, Kim HT, Lee KT, Yang S, Lee JK, Lee KH and Rhee JC: KML001 inhibits cell proliferation and invasion in pancreatic cancer cells through suppression of NF- $\kappa \mathrm{B}$ and VEGF-C. Anticancer Res 34: 3469-3474, 2014.

14. Yoon JS, Hwang DW, Kim ES, Kim JS, Kim S, Chung HJ, Lee SK, Yi JH, Uhm J, Won YW, et al: Anti-tumoral effect of arsenic compound, sodium metaarsenite (KML001), in nonHodgkin's lymphoma: An in vitro and in vivo study. Invest New Drugs 34: 1-14, 2016.

15. d'Adda di Fagagna F, Reaper PM, Clay-Farrace L, Fiegler H, Carr P, Von Zglinicki T, Saretzki G, Carter NP and Jackson SP: A DNA damage checkpoint response in telomere-initiated senescence. Nature 426: 194-198, 2003.

16. Rogakou EP, Pilch DR, Orr AH, Ivanova VS and Bonner WM: DNA double-stranded breaks induce histone H2AX phosphorylation on serine 139. J Biol Chem 273: 5858-5868, 1998.

17. Bartek J and Lukas J: DNA damage checkpoints: From initiation to recovery or adaptation. Curr Opin Cell Biol 19: 238-245, 2007.

18. Jazayeri A, Falck J, Lukas C, Bartek J, Smith GC, Lukas J and Jackson SP: ATM- and cell cycle-dependent regulation of ATR in response to DNA double-strand breaks. Nat Cell Biol 8: 37-45, 2006.

19. Zhang B, Suer S, Livak F, Adediran S, Vemula A, Khan MA, Ning $Y$ and Hussain A: Telomere and microtubule targeting in treatment-sensitive and treatment-resistant human prostate cancer cells. Mol Pharmacol 82: 310-321, 2012.

20. Thornberry NA and Lazebnik Y: Caspases: Enemies within. Science 281: 1312-1316, 1998. 
21. Yoon JS, Kim ES, Park BB, Choi JH, Won YW, Kim S and Lee YY: Anti-leukemic effect of sodium metaarsenite (KML001) in acute myeloid leukemia with breaking-down the resistance of cytosine arabinoside. Int J Oncol 46: 1953-1962, 2015.

22. Blackburn EH: Telomeres and telomerase: Their mechanisms of action and the effects of altering their functions. FEBS Lett 579: 859-862, 2005.

23. Moyzis RK, Buckingham JM, Cram LS, Dani M, Deaven LL, Jones MD, Meyne J, Ratliff RL and Wu JR: A highly conserved repetitive DNA sequence, (TTAGGG)n, present at the telomeres of human chromosomes. Proc Natl Acad Sci USA 85: 6622-6626, 1988.

24. Masutomi K, Yu EY, Khurts S, Ben-Porath I, Currier JL, Metz GB, Brooks MW, Kaneko S, Murakami S, DeCaprio JA, et al: Telomerase maintains telomere structure in normal human cells. Cell 114: 241-253, 2003.
25. Shay JW and Gazdar AF: Telomerase in the early detection of cancer. J Clin Pathol 50: 106-109, 1997.

26. Chou WC, Hawkins AL, Barrett JF, Griffin CA and Dang CV: Arsenic inhibition of telomerase transcription leads to genetic instability. J Clin Invest 108: 1541-1547, 2001.

27. Wang ES, Wu K, Chin AC, Chen-Kiang S, Pongracz K, Gryaznov S and Moore MA: Telomerase inhibition with an oligonucleotide telomerase template antagonist: In vitro and in vivo studies in multiple myeloma and lymphoma. Blood 103: 258-266, 2004 